\title{
EFFECTS OF THE MAGNETIC FIELD ON DIFFERENT FORMS OF EMBRYONIC LOCOMOTOR ACTIVITY OF NORTHERN PIKE, ESOX LUCIUS L.
}

\author{
Aleksander WINNICKI *, Agata KORZELECKA-ORKISZ, \\ Andrzej SOBOCIŃSKI, Adam TAŃSKI, Krzysztof FORMICKI
}

\section{Division of Fish Anatomy and Embryology, Agricultural University of Szczecin, Poland}

Winnicki A., Korzelecka-Orkisz A., Sobociński A., Tański A., Formicki K., 2004. Effects of the magnetic field on different forms of embryonic locomotor activity of northern pike, Esox lucius L. Acta Ichthyol. Piscat. 34 (2): 193-203.

Background. The magnetic field is known to exert its influence on both adult and juvenile fishes, as well as the embryos. The effects are diversified and pertain to, practically all, life aspects of an individual. Another aspect of this issue can be the existing and still growing magnetic pollution of the natural environment. In view of the above we decided to study the embryonic motorics of fish, exemplified by pike, affected by constant- and alternating magnetic fields.

Material and methods. Eggs of pike (Esox lucius L.) after period of adaptation (control) were subjected to 30-min action of the magnetic field (constant $4 \mathrm{mT}$ and alternating $15 \mathrm{mT}$ ). The inflicted changes in the embryonic motorics were observed under a microscope and recorded on videotape.

Results. The following aspects of the embryogenesis were affected:

- Quasi-peristalsis (increased angular velocity and the amplitude of ectoplasmic waves - at the stages of blastula end gastrula).

- Heart muscle action (in alternating field-short, small acceleration in the heartbeat is followed by a sudden rise of the number of contractions).

- Somatic motorics (no visible effect of neither constant- nor alternate field).

Conclusions. Three different mechanism of the magnetic field are taken into consideration: a) directly on actomyosin structures in the quasi-peristalsis, b) on automatic centres of the developing heart, and c) on developing structures of the central nervous system (no effect presently observed).

Key words: magnetic field, fish, pike, embryonic locomotor activity

${ }^{*}$ Correspondence: Prof. dr hab. Aleksander Winnicki, Zakład Anatomii i Embriologii, WNoŻiR, Akademia Rolnicza, ul. Kazimierza Królewicza 4, 71-550 Szczecin, Poland, e-mail: embryo@fish.ar.szczecin.pl 


\section{INTRODUCTION}

The Earth's magnetic field affects directional responses of live organisms, from bacteria to insects and crustaceans to amphibians, reptiles, birds, and mammals (Keeton 1971, Gould 1980, Lohmann et al. 1995, Yano et al. 1996). Due to magnetite $\left(\mathrm{Fe}_{3} \mathrm{O}_{4}\right)$ particles located in certain sites of the brain skull, the fish such as chum salmon, Oncorhynchus keta (Walbaum, 1792); sockeye salmon, O. nerka (Walbaum, 1792); Chinook salmon, O. tschawytscha (Walbaum, 1792); Atlantic salmon, Salmo salar L., European eel, Anguilla anguilla (L.); and yellowfin tuna, Thunnus albacares (Bonnaterre, 1788) are sensitive to magnetic stimuli as well and use the Earth's magnetic field to help them navigate during migrations (Tesch 1974, Quinn and Groot 1983, Potter and Moore 1991, Ogura et al. 1992).

The knowledge on magnetic effects on fish has been utilised during studies on application of constant ferritic magnets in trap-type fishing gear (Formicki et al. 2000a, 2001a, 2002a). The field generated by the magnets was found to significantly enhance the performance of the traps by acting like a fish attracting factor of a kind: in all likelihood, the fish responded to it thanks to their "curiosity reflex" (Pavlov 1951-52).

The simultaneous research has demonstrated that magnetic field affects not only adult fish, but also juveniles. The effects are multiple and basically involve all life functions of an individual (Formicki et al. 1993, Wannitikul et al. 1993, Winnicki et al. 1993, 1996, Formicki and Winnicki 1996, Perkowski and Formicki 1997, Formicki and Perkowski 1998, Formicki et al. 1999, Korzelecka-Orkisz et al. 2003).

With respect to the directional responses of juveniles, a number of studies have demonstrated that already at early ontogenesis both the geomagnetic field and the artificially generated magnetic field induce fish embryos to position themselves so that their body symmetry axis is parallel to the field lines, the north-south positioning of the body being the preferred one (Formicki et al. 1997, 1998, 2000b, 2001b, 2002b).

Observations on trout larvae showed the magnetic field to play a significant role at that life stage by eliciting certain locomotor responses of juvenile organisms in the form of directional movement in the water (Sadowski et al. 2003).

The aim of the present study was to look for a material basis of the directional responses of adults by trying to find their rational explanation in the embryogenesis. This would assist in finding a general answer to the question whether the specific forms of locomotor behaviour of the adults are their acquired trait or an innate one, originating early in the ontogenesis.

It was thus decided to follow the effects of constant (4 mT) and alternating (15 mT, $50 \mathrm{~Hz}$, sinusoid) magnetic fields on certain manifestation of locomotor responses in perch: the quasi-peristalsis, somatic movements, and the cardiac muscle activity.

\section{MATERIALS AND METHODS}

The study was carried out in spring in the isothermal laboratory of the Division of Fish Anatomy and Embryology, Agricultural University of Szczecin. 
Reproductive products, collected from the ready-to-spawn northern pike, Esox lucius L. spawners were fertilised dry. The fertilised and activated eggs were incubated at $7^{\circ} \mathrm{C}$ in basins equipped in hydromechanic devices ensuring appropriate oxygenation of water and its exchange.

Changes in the effects of constant and alternating magnetic fields on different types of embryonic locomotor activity (quasi-peristalsis, cardiac muscle contraction rhythms, somatic movements) were followed.

Magnetic field was generated by a computer-driven magnetic field source $(0-60 \mathrm{~Hz})$ used in biological research (constructed at the Institute of Telecommunications and Acoustics, Wrocław Technical University), consisting of:

- an electronic unit, composed of a magnetic field generator, water-cooled current amplifiers, magnetic field measurement system, protective systems, and a power source;

- a set of water-cooled magnetic coils;

- a driving programme.

Individual eggs were placed, between induction coils, in $1 \times 1 \mathrm{~cm}$ chambers (because of their size, the chambers could always be placed in the same spot in the magnetic field; at the same time; the amount of water in the chamber was sufficient for regular respiration). The field generated in the space between the coils was uniform. After a 10-min adaptation (each time treated as a control), the magnetic field was switched on for 30 minutes. The constant and alternating field values were $4.0 \mathrm{mT}$ and $15.0 \mathrm{mT}(50 \mathrm{~Hz}$, sinusoid), respectively.

The locomotor activity was studied with the aid of a special experimental system, already used in our earlier research (Winnicki and Korzelecka 1997). The system consists of:

- a stereomicroscope, to examine and select study objects;

- a CCD digital camera (Sony), to transmit images of the objects selected under the microscope to the computer screen;

- an SVHS video recorder (Sony), to record the images for further detailed analysis of movements performed by various structures;

- a computer with specialised software: Multiscan v. 6.08 (image analysis) and Statistica 5.0 (statistical treatment).

Experimental

- Quasi-peristalsis*: a single full cycle of the quasi-peristaltic wave was timed (control). Once a magnetic field was switched on, the time of the wave's return to the original spot $(T)$ was measured; the value obtained was converted to angular velocity with the formula $V_{\text {angular }}=2 \Pi / T$ and referred to the control. The artificial magnetic field-induced quasi-peristalsis was observed in embryos at the blastula

\footnotetext{
* quasi-peristalsis is a movement performed by the egg cell ectoplasm; the movements are visible as a parallel translocation, on the yolk sphere surface, of crests, the translocations inducing swirling motion of the embryonic plate and revolving movements of the entire egg cell (Korzelecka 1999)
} 
( $3 \mathrm{dd}$ (degree days); time from fertilisation) and gastrula stages ( $1 / 2$ epiboly at $20 \mathrm{dd}$; time from fertilisation) as well as in those that began performing somatic movements ( $50 \mathrm{dd}$, time from fertilisation).

- Heart: changes in the heart rate of embryos (prior to hatching, $110 \mathrm{dd}$, time from fertilisation), before and after exposure to magnetic field. The number of contractions was measured at 30-second intervals and converted to the number of contractions per minute; that value was referred to the control (regarded as 100\%).

- Somatic muscle contractions: the number of embryonic body movements was counted, taking each movement into account, during exposure to magnetic field and compared to the number of movements performed prior to the exposure (control).

\section{RESULTS}

The experiments showed the changes induced by the constant and magnetic field to occur with a fair degree of regularity, both with respect to the quasi-peristaltic movements and heartbeat acceleration.

The quasi-peristalsis angular velocity at the blastula stage embryos exposed to magnetic fields tended to increase during the wave cycle. During the initial 8 turns, the quasi-peristaltic wave accelerated fairly slowly (Fig. 1a), the acceleration increasing statistically significantly with time. Particularly noteworthy were much deeper troughs and much higher crests of the ectoplasmic wave.

A similar trend was displayed by the quasi-peristalsis at the gastrula stage embryos. From the 9th turn on, the angular acceleration was significantly higher, compared with the control (Fig. 1b).

In a fully formed embryo, the angular velocity increased somewhat faster: after 15 minutes of exposure to the magnetic field; during the 4th turn the angular velocity was significantly higher than that in the control (Fig. 1c).

Constant magnetic field, too, was observed to increase the angular velocity of the quasi-peristaltic wave of the ectoplasm: the acceleration occurred during the 8th turn in the blastula (Fig. 2a) and during the 10th turn in the gastrula (Fig. 2b). A change in direction and value of a magnetic field the embryos were exposed to affected the embryonic locomotor activity. The effect was substantial, as it involved a change in the rate of the trough and crest movement on the yolk sphere surface.

On the other hand, constant magnetic field did not intensify the peristalsis in the yolk sac walls once gastrulation had been completed (Fig. 2c), although an increasing trend was noticeable.

The heart muscle activity in response to different magnetic fields was more diverse. The constant magnetic field induced an already known response (Winnicki et al. 1993) in the form of a significant gradual acceleration of the hear rate (Fig. 3a).

In the alternating field, on the other hand, that response was overlain by a rapid heart rate acceleration when the maximum would have been reached in the constant field, and a decreasing trend was observed (Fig. 3b). 
a

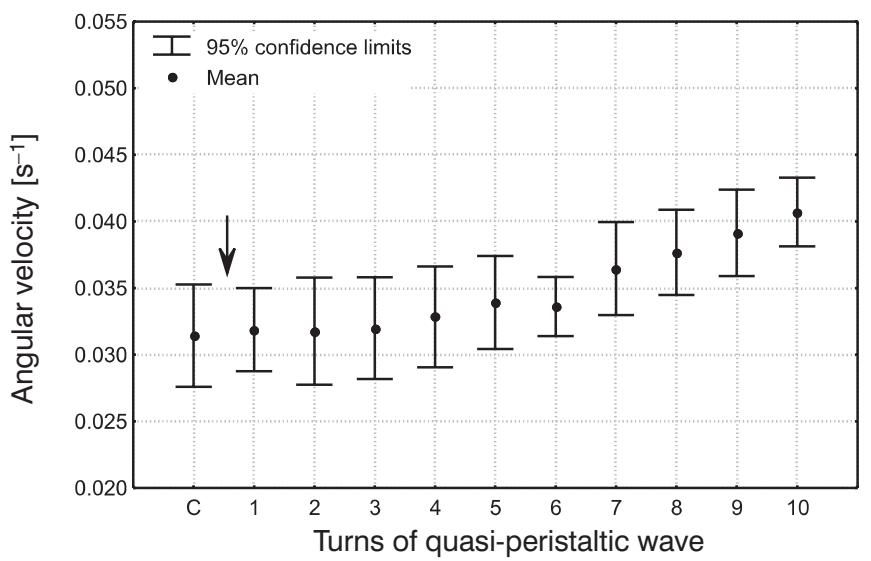

b

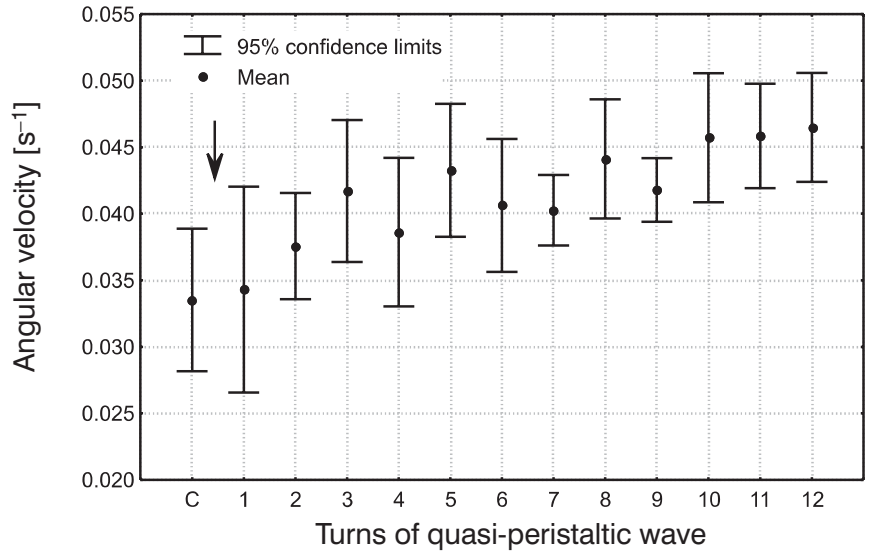

c

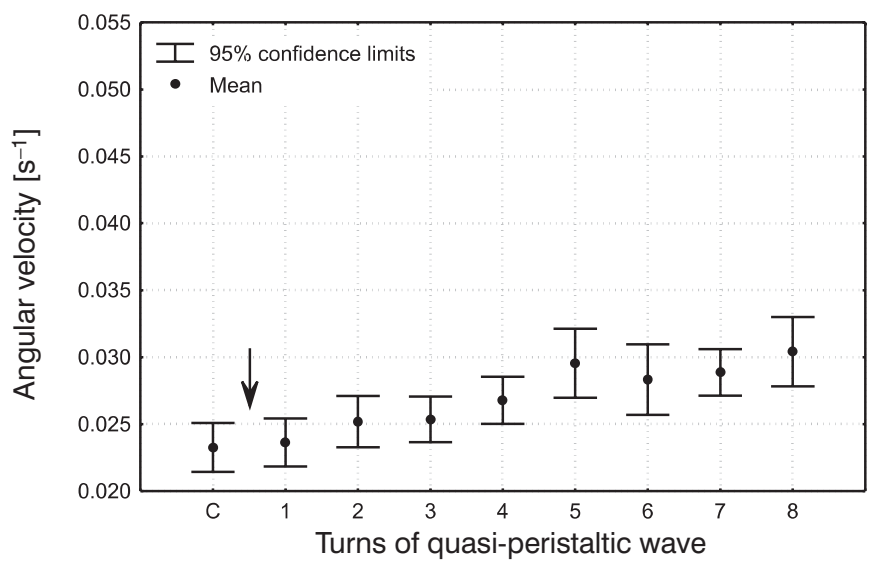

Fig. 1. Changes in angular velocity of quasi-peristaltic wave of different embryo stages exposed to alternating magnetic field; $\mathrm{n}=11$; $\mathrm{a}$, blastula; $\mathrm{b}$, gastrula; c, embryo; C, control; $\downarrow$, magnetic field switched on 
a

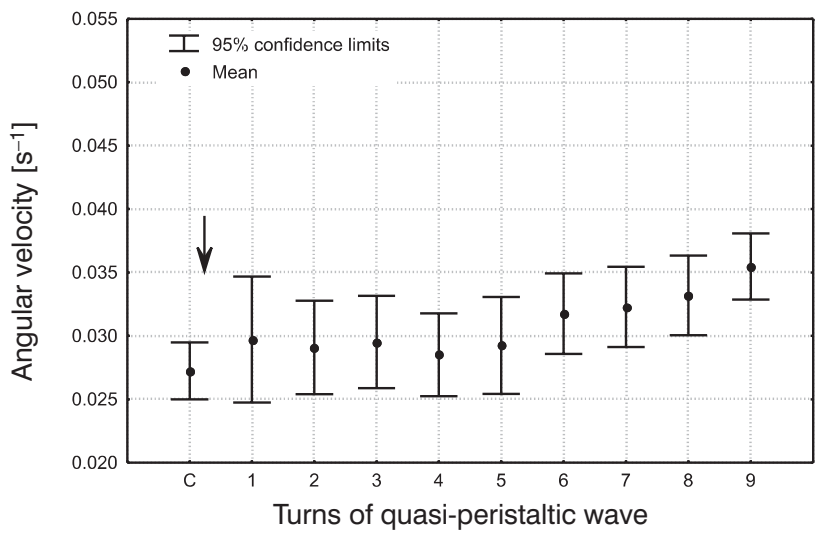

b

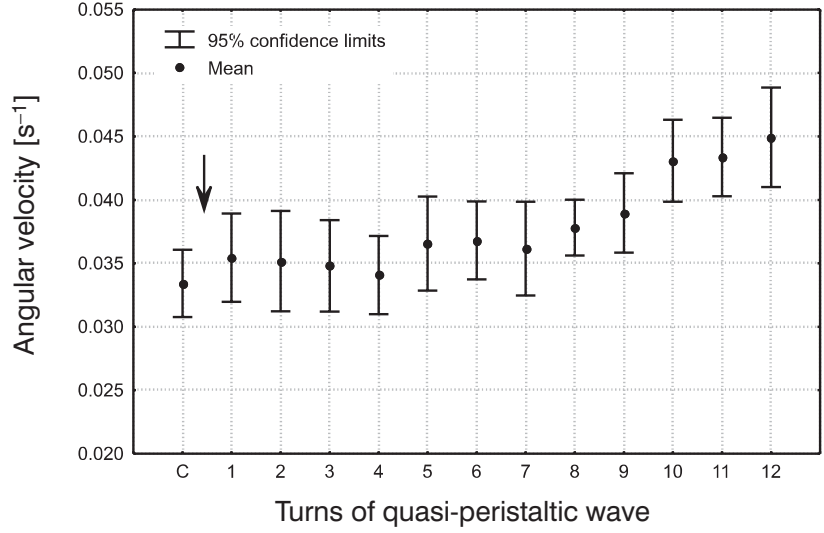

c

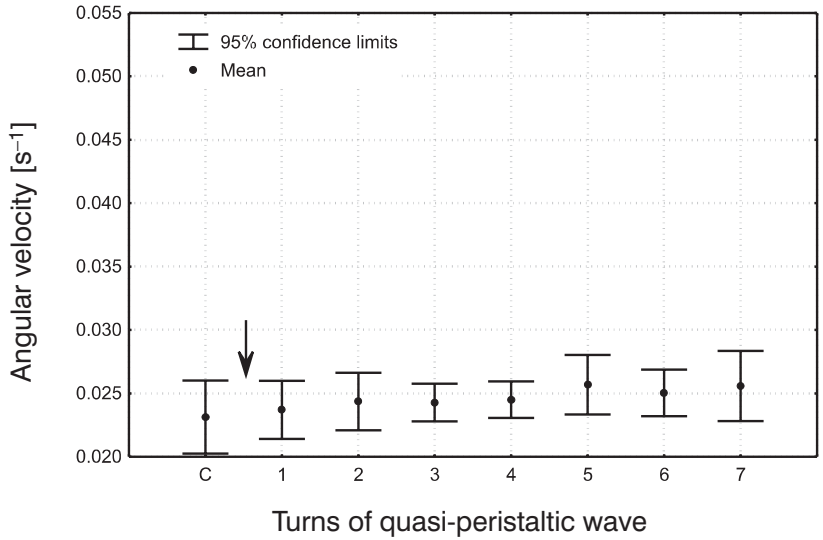

Fig. 2. Changes in angular velocity of quasi-peristaltic wave of different embryo stages exposed to constant magnetic field; $\mathrm{n}=11$; $\mathrm{a}$, blastula; $\mathrm{b}$, gastrula, c, embryo; C, control; $\downarrow$, magnetic field switched on 

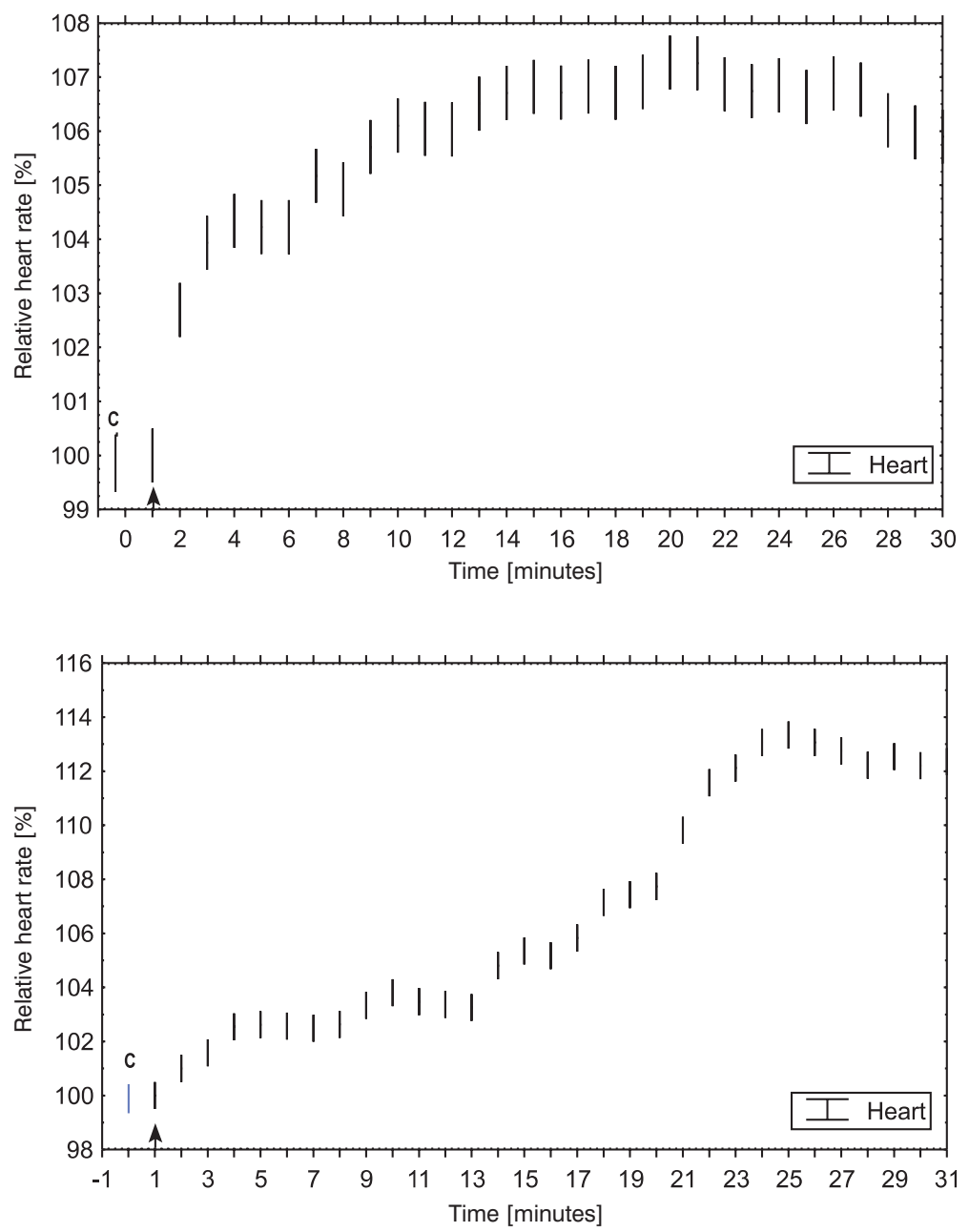

Fig. 3. Change in heart rate of pike embryos exposed to magnetic field: a, constant; b, alternating; C, control; $\uparrow$, magnetic field switched on

The somatic locomotor activity showed no response to either the constant or alternating magnetic field.

\section{DISCUSSION}

As shown by the study, of the three major type of embryonic locomotor activity, i.e. quasi-peristalsis, heart muscle contractions, and somatic movements of the embryo, it is the first two that directly respond to changes in magnetic field. Under the experimental conditions maintained, effects on the somatic movements were minimal or absent altogether. 
The mechanism of magnetic field effects on complexes of contractile structures differs between the cases.

With respect to the quasi-peristalsis, a clear acceleration of the movement of ectoplasmic contraction wave was seen. In other words, the magnetic field produced an identical effect in all the actomyosin complexes of the ectoplasm. Deeper troughs and higher crests can be taken as indication that the magnetic field induces a "full contraction", the observed acceleration of the wave movement pointing to acceleration of functional stimulation (alternation of electrostatic charge in myofilaments) within the wave protoplasm, characteristic of spontaneous locomotor activity.

Interestingly, already at early ontogenesis, bunches of contractile filaments show an increasing tendency towards assuming a certain spatial position with respect to the magnetic field lines (parallel positioning in this case). In effect, this tendency is manifested as a specific directional and spatial response of the developing embryos towards the magnetic field lines, which has been convincingly demonstrated in our earlier studies (Formicki et al. 1997, 2001b, 2002b).

It is necessary to note that the ectoplasm locomotor activity in response to magnetic field could have been and was affected by an increased oxygen demand associated with increasing metabolism, accompanying intensified locomotor activity.

As shown by both this study and earlier research (Formicki and Winnicki 1996), effects of magnetic field on the heart muscle activity was somewhat different. The cardiac muscle's locomotor response to exposure to a magnetic field was almost instantaneous, but the muscle contractions increased gradually, to reach the maximum after 30 minutes $\left(\right.$ at $\left.7^{\circ} \mathrm{C}\right)$. This can be taken as evidence that magnetic field affects myofilaments not directly, but indirectly, via the already formed automatism centres that control the heart rhythm. This has been already pointed out by Harary (1962) and Smith and Berndt (1964), and also indirectly by Bloom (1970) who studied magnetic field effects on heart muscle fragments (sections).

The cardiac muscle is noteworthy by the difference in its reaction to constant and alternating magnetic fields. The increase in heartbeat rate in the latter was by almost $70 \%$ higher than the increase observed as a result of exposure to constant magnetic field. This may be regarded as evidence that the response to the constant magnetic field occurs only at the moment the field is switched on, following which a state of equilibrium (a "status quo" of a kind) is maintained. In the case of the alternating field, its impulses reach the automatism centre at short time intervals, inducing a specific continuous and increasing physiological alteration of contractile structures.

The study failed to demonstrate any significant effect of a magnetic field, either constant or alternating, on somatic movements of pike embryos; a weak trend only was observed. This specific absence of a response on the part of the somatic muscle layer may be interpreted in the light of a strict coordination of somatic movements by the central nervous system and a total subordination of somatic movements to nervous centres during late embryogenesis. 
In addition, not unimportant is the fact that somatic movements of an embryo at that phase are still limited due to spatial limitation imposed by the egg membranes surrounding the embryo. The somatic movements themselves do not play the important role they assume after hatching (swimming, escape from danger, feeding). Thus, at final stages of embryogenesis, as a result of obvious biological constraints, the individual's reflex responses to an external stimulus such as magnetic field, have not developed yet.

It may be then inferred that the basis of all directional responses to the magnetic field, displayed by an individual regardless of its developmental stage (embryo, larva, adult), lies always within contractile structures in the cell protoplasm. The diversity of forms of responses and their external manifestations depend on the integration level at different developmental stages and on the biological role the structures are to play.

\section{ACKNOWLEDGEMENTS}

The study was supported by the State Committee for Scientific Research (KBN) grant No. 5 P06D 02419.

\section{REFERENCES}

Bloom S., 1970. Spontaneous rhythmic contraction of separated heart cells. Science 167: $1727-1729$.

Formicki K., Bonisławska M., Jasiński M., 1997. Spatial orientation of trout (Salmo trutta L.) and rainbow trout (Oncorhynchus mykiss Walb.) embryos in natural and artificial magnetic field. Acta Ichthyologica et Piscatoria 27 (2): 29-40.

Formicki K., Lucewicz O., Winnicki A., Domagała J., 1999. Changes in embryogenesis and sex determination in trout (Salmo trutta L.) in alternating magnetic field. XXVIth General Assembly, International Union of Radio Science, University of Toronto, Toronto, Ontario, Canada, August 13-21, 1999, Abstracts p. 630.

Formicki K., Perkowski T., 1998. The effect of a magnetic field on the gas exchange in rainbow trout Oncorhynchus mykiss embryos (Salmonidae). Italian Journal of Zoology 65 (Suppl.): 475-477.

Formicki K., Sobociński A., Winnicki A., 1993. Dynamics of water uptake by trout (Salmo trutta L.) eggs exposed after activation to magnetic field. pp. 759-760. In: Blank M., (ed.) Electricity and magnetism in biology and medicine. San Francisco Press, San Francisco.

Formicki K., Tański A., Sobociński A., 2001a. A directional responses of fish to changes in magnetic field in natural environment. Xth European Congress of Ichthyology, "In the heart of Europe", Prague, Czech Republic, 3-7 September 2001, Book of Abstracts p. 119.

Formicki K., Tański A., Winnicki A., 2000a. Preliminary results of studies on magnetic field effect on semi-circular fyke net. Folia Universitatis Agriculturae Stetinensis 214, ser. Piscaria (27): 69-74.

Formicki K., Tański A., Winnicki A., 2001b. Axis of symmetry orientation in trout (Salmo trutta L.) embryos exposed to constant magnetic field: emergence of the process. 2001 Asia-Pacific Radio Science Conference, AP-RASC'01, Chuo University, Tokyo, Japan, Aug 1-4, 2001, Conference Digest p. 407. 
Formicki K., Tański A., Winnicki A., 2002a. Effects of magnetic field on the direction of fish movement in the natural conditions. General Assembly URSI 2002, Maastricht, Netherlands. K2.O.5 (842) pp.1-3.

Formicki K., Tański A., Winnicki A., Duchiewicz J., 2000b. Wpływ pola magnetycznego na ułożenie osi symetrii rozwijających się zarodków troci (Salmo trutta L.) i pstrąga tęczowego (Oncorhynchus mykiss Walb.). [Magnetic field effects on the arrangement of body symmetry axis in developing embryos of trout (Salmo trutta L.) and rainbow trout (Oncorhynchus mykiss Walb.).] pp. 328-334. In: Krajowe sympozjum telekomunikacji '2000. [All nation's symposium on telecommunication 2000.], 6-8 September 2000, Akademia Techniczno-Rolnicza w Bydgoszczy. Published by: Oficyna Wydawnicza Politechniki Warszawskiej, Warszawa. (In Polish.)

Formicki K., Tański A., Winnicki A., 2002b. Ukierunkowanie przestrzenne rozwijających się zarodków ryb w polu magnetycznym. [Spatial positioning of developing fish embryos in magnetic field.] 28th Symposium of the Polish Society of Histo- and Cytochemists and the 3rd Polish Conference of the Developmental Biology Society, Międzyzdroje 4-7 September 2002 p. 42. (In Polish.)

Formicki K., Winnicki A., 1996. Effects of constant magnetic field on cardiac muscle activity in fish embryos. Publicaciones Especiales Instituto Español De Oceanografía 21: 287-292.

Formicki K., Winnicki A., 1998. Reaction of fish embryos and larvae to constant magnetic fields. Italian Journal of Zoology 65 (Suppl.): 479-482.

Gould J.L., 1980. The case for magnetic sensitivity in birds and bees (such as it is). American Scientist 68: 256-267.

Harary I., 1962. Heart cells in vitro. Scientific American (May 206): 141-152.

Keeton W.T., 1971. Effects of magnets on pigeons homing. Proceedings of the National Academy of Sciences 68: 102-106.

Korzelecka A., 1999. Motoryka embrionalna u ryb kostnoszkieletowych. [Embryonic locomotor activity in teleost fishes.] PhD Thesis, Agricultural University of Szczecin, Poland. (In Polish.)

Korzelecka-Orkisz A., Sobociński A., Formicki K., Winnicki A., 2003. Wpływ pola magnetycznego na motorykę embrionalną szczupaka Esox lucius L. [Effects of magnetic field on locomotor activity of pike (Esox lucius L) embryos.] pp. 95-100. In: Zakęś Z., Demska-Zakęś K., Krzywosz T., Wolnicki J., (eds.) Ryby drapieżne, rozród, podchów, profilaktyka. [Predatory fishes: reproduction, growing, prophylaxis.] Wydawnictwo IRŚ, Olsztyn. (In Polish.)

Lohmann K.J., Pentcheff N.D., Nevitt G.A., Stetten G.D., Zimmer-Faust R.K., Jarrard H.E., Boles L.C., 1995. Magnetic orientation of spiny lobsters in the ocean: Experiments with undersea coil systems. Journal of Experimental Biology 198: 2041-2048.

Ogura M., Kato M., Arai N., Sasada T., Sasaki Y., 1992. Magnetic particles in chum salmon (Oncorhynchus keta): Extraction and transmission electron microscopy. Canadian Journal of Research 70 (5): 874-877.

Pavlov I.P., 1951-52. Polnoe sobranie sočinenij v šesti tomach v vos'mi knigah. [Complete collection of works in six volumes in eight books.] Izdatel'stvo Akademii Nauk SSSR, Moskva-Leningrad.

Potter T., Moore A., 1991. Salmon migration mystery: Scientists magnetic navigation theory. Fishing News 4030: 3. 
Perkowski T., Formicki K., 1997. The effect of constant magnetic fields on respiration on rainbow trout (Oncorhynchus mykiss Walb.) embryos. Acta Ichthyologica et Piscatoria 27 (2): 41-56.

Quinn T.P., Groot C., 1983. Orientation of chum salmon (Oncorhynchus keta) after internal and external magnetic field alteration. Canadian Journal of Fisheries and Aquatic Sciences 40: $1598-1606$.

Sadowski M., Tański A., Formicki K., Winnicki A., 2003. Zachowanie się larw troci (Salmo trutta L) w stałym polu magnetycznym. [The behaviour of trout (Salmo trutta L) larvae in constant magnetic field.]. pp. 133-137. In: Zakęś Z., Demska-Zakęś K., Krzywosz T., Wolnicki J., (eds.) Ryby drapieżne, rozród, podchów, profilaktyka. [Predatory fishes: reproduction, growing, prophylaxis.] Wydawnictwo IRŚ, Olsztyn. (In Polish.)

Smith Jr T.E., Berndt W.O., 1964. The establishment of beating myocardial cells in longterm culture in fluid medium. Experimental Cell Research 36: 179-191.

Tesch F.W., 1974. Speed and direction of silver and yellow eels, Anguilla anguilla, released and tracked in the open North Sea. Archiv für Fischereiwissenschaft 23: 181-197.

Wannitikul P., Winnicki A., Formicki K., 1993. Effect of constant magnetic fields on fish melanophores in vivo and vitro. pp. 849-850. In: Blank M., (ed.) Electricity and Magnetism in Biology and Medicine. San Francisco Press, San Francisco.

Winnicki A., Formicki K., Korzelecka A., Sobociński A., 1993. Cardiac responses of pike (Esox lucius L.) embryos and larvae to constant magnetic field. Archives of Polish Fisheries 1 (2): 87-93.

Winnicki A., Formicki K., Sobociński A., 1996. Application of constant magnetic field in transportation of gametes and fertilised eggs of salmonid fish. Publicaciones Especiales Instituto Español De Oceanografía 21: 301-305.

Winnicki A., Korzelecka A., 1997. Morphomechanical aspects of the development of the bleak (Alburnus alburnus L.). Acta Ichthyologica et Piscatoria 27 (2): 17-27.

Yano A., Ogura M., Sato A., Sakaki Y., Ban M., Nagasawa K., 1996. Development of ultrasonic telemetry technique for investigating the magnetic sense of salmonids. Fisheries Science 62 (5): 698-704. 